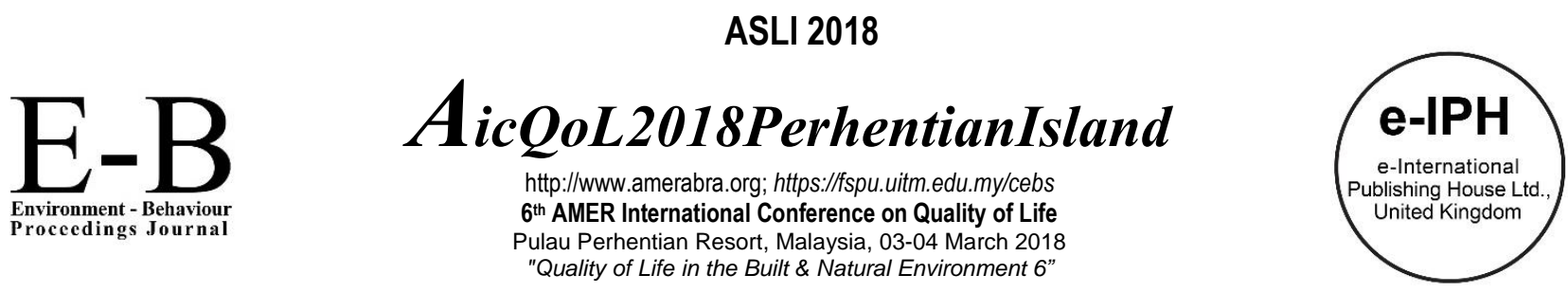

\title{
The Rise of Rooftop Urban Farming at George Town, Penang
}

\author{
Nur Hayati Hashim, Nur Huzeima Mohd Hussain, Asmat Ismail \\ Faculty of Architecture, Planning \& Surveying, University Technology MARA Perak, Malaysia. \\ nurhayatie.hashim@gmail.com, nurhu154@perak.uitm.edu.my, asmat926@perak.uitm.edu.my \\ Tel: +6019-3665207
}

\begin{abstract}
Urban farming is growing in popularity for taking advantage of unused spaces on the rooftop in cities. This issue is becoming fundamentals due to the scarcity of land issue, urbanisation and urban poverty. This paper presents a brief method used in exploring the potential of implementing urban farming on the rooftop areas. The research aims to measure the potential of the rooftop as urban farming at George Town, Penang. This study adopted quantitative method using the questionnaire to conduct a survey. The result shows significant findings of reliability test of Cronbach's Alpha.
\end{abstract}

Keywords: Urban Faming; Rooftop; George Town, Penang; Highrise Residential

eISSN: 2398-4287@ 2018. The Authors. Published for AMER ABRA cE-Bs by e-International Publishing House, Ltd., UK. This is an open access article under the CC BYNC-ND license (http://creativecommons.org/licenses/by-nc-nd/4.0). Peer-review under responsibility of AMER (Association of Malaysian Environment-Behaviour Researchers), ABRA (Association of Behavioural Researchers on Asians) and cE-Bs (Centre for Environment-Behaviour Studies), Faculty of Architecture, Planning \& Surveying, Universiti Teknologi MARA, Malaysia.

DOI: https://doi.org/10.21834/e-bpj.v3i7.1242

\subsection{Introduction}

The issues of raising the urban population become nerve-racking nowadays. From the study by Rasmuna \& Mohd Rashid (2015), it shows that the projection of urban population will increase by $60 \%$ by 2025 from $58 \%$ in 2014 . This issue is line with the migrations of the rural folks to the urban area. Thus, the urbanisation nowadays changes the human demands and straining natural resources. There are many ways in consideration of the place as urban area according to Tarmiji et al. (2011) which is urban population density thresholds, census or jurisdictional definitions, economic criteria and the presence of human-made structures.

In Malaysia context, the urban population growth will reach $75 \%$ of the total population in 2020 compared to $65.4 \%$. According to Tarmiji et al. (2012), the increasing of urban area in Malaysia is focusing on Kuala Lumpur, Penang and Johor. Due to the increase of urban area, the development in Penang has grown tremendously with high rise building to cater the demand of housing due to limited land in Penang Island. Thus, it influenced the limitation of agricultural land. Consequently, the green roof has become one of the most potential places to create green space.

Recently, the application of green roof urban farming has become popular in most of the urban country in the world. The evidence from other developing countries can see in Singapore, Japan, USA and more (Nur Hayati, Nur Huzeima \& Asmat, 2016). The significant of urban farming in an urban area is not only to ensure the continues food supply alone, but it can help in reducing the urban poverty, increase food insecurity, jobs opportunities to the community and last but not least towards the environment.

This paper will focus on the ideas, issues and potential of rooftop urban farming concepts in George Town, Penang. The idea of urban farming is more popular and used in urban areas. This paper objective would be focusing on the selection of case study and would explain about the pilot study result on potential of urban farming on rooftop. The research will enhance the idea of greening the cities through rooftop urban farming. The study will focus on the potential of urban farming regarding space and users.

eISSN: 2398-4287@ 2018. The Authors. Published for AMER ABRA cE-Bs by e-International Publishing House, Ltd., UK. This is an open access article under the CC BYNC-ND license (http://creativecommons.org/licenses/by-nc-nd/4.0/). Peer-review under responsibility of AMER (Association of Malaysian Environment-Behaviour Researchers), ABRA (Association of Behavioural Researchers on Asians) and cE-Bs (Centre for Environment-Behaviour Studies), Faculty of Architecture, Planning \& Surveying, Universiti Teknologi MARA, Malaysia.

DOI: https://doi.org/10.21834/e-bpj.v3i7.1242 


\subsection{The Definitions}

\section{Green Roof}

Kortright (2001) defines the green roof as an open space with any planting that separated from the ground by building or other structure. The benefit from green roof is tremendously well known not limited to environmental benefits only but for the economy as well. The benefits of the green roof towards the environment are for temperature moderation, reducing urban heat island, slowing the water runoff and more (Asmat et al., 2011). In contrast, the aesthetic seems to be less critical than some other benefit listed here. The latest widespread use of green roof is the production of food. Rooftop urban farming is one of the reasonable attempts to urbanites.

\section{Urban Farming}

The practices of urban farming around the world are different, but all were having same purpose which is contributing to the urban food security and resilience. Therefore, the meaning of urban farming also is in various versions. Urban farming can be defined as a localised food system wherein the production, consumption, recycling of food occurs in the city (Smit et al., 1996). Besides, the definitions from FAO (2007) and RUAF(2007) defined the meaning of urban farming as growing plants and raising the animals within and around the cities. Sanye-Mengual (2015) described the definition of urban farming as the farming operations around the cities beyond the food production and provides environmental and social service as well as support the local economies. Thus, for this paper, the urban farming can be defined as an activity of farming happened in the urban area not only for food production but also for other benefits towards social, economic as well as environment. The potential of urban farming is seen to be in positive vibes in Malaysia.

\subsection{The Significance of Urban Farming}

In coming years, Food Agriculture Organization (FAO) estimated that the food prices would increase and affect the food crisis in the impoverished country. Thus, in preventing the food security, the three ways stated by Giraldo (2008), needs to be achieved are; 1) to ensure the adequate food production; 2) providing stability in foods flow, and 3) guaranty the access of available foods to the needs. The significance of urban farming in Malaysia in ensuring the food sustainability has counted in the policies and strategic plan. In Malaysia's third national agricultural policy (1998-2010), one of the primary objectives is to enhance the food security (Ministry of Agriculture Malaysia). Furthermore, the other policy is National Agro-food Policy (NAP) 2011-2020 driven by the development of agriculture sector in Malaysia. In this policy, the challenges of agriculture in domestic and global been addressed.

In this research, the aims are to identify the potential of the green roof as urban farming. The primary objectives of this study are to identify the potential of urban agriculture on the rooftop in George Town, Penang. This goal seeks to identify and understand whether the main factors which are space and users will influence the potential of urban farming on the rooftop

\subsection{Methodology}

\subsection{Case study: George Town, Penang}

Malaysia is one of the countries that have rapid urban development. Thus, the increasing pattern of population migration growth affected in west coast urban area like Kuala Lumpur, Penang, Johor and other (Tarmiji et al., 2012). Thus, the urban west regions are potentially in constructing rooftop urban farming. Therefore, the selection of Penang as a case study in this research is impeccable due to the rapid development urban area in the limited land, particularly in island area. From the previous research, the selection of site based on the two principal which is 1) the population size; 2) land use for residential.

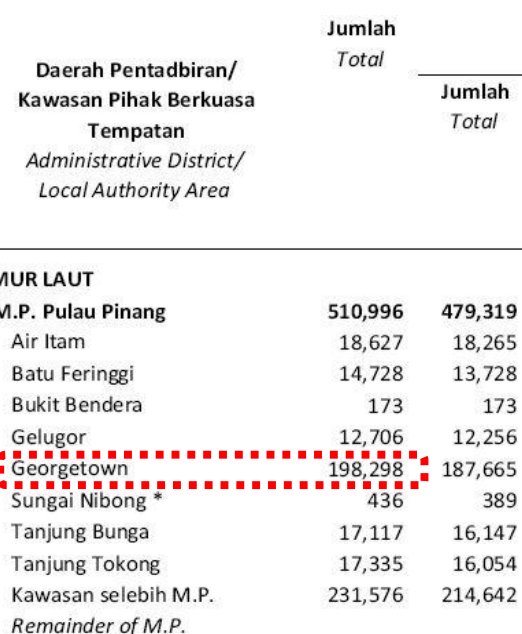

Figure 1: Total Population in Northeast district. Source: Department of Statistic Malaysia, (2015)

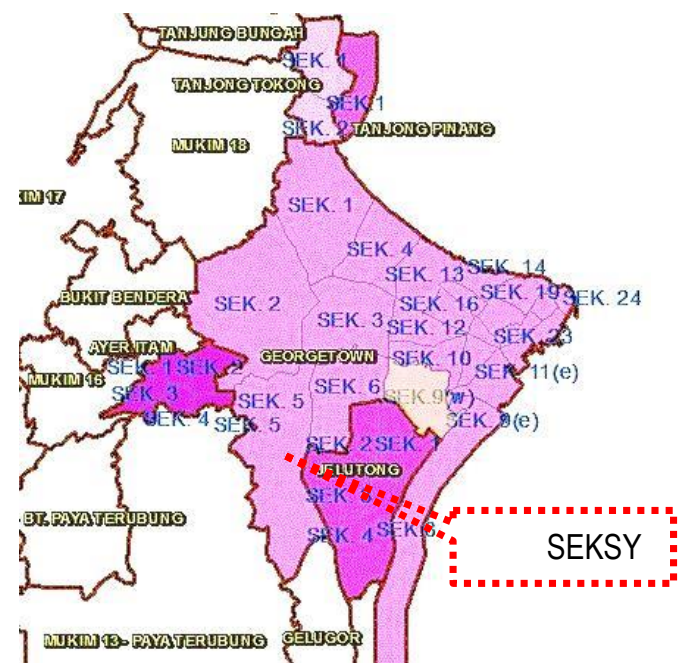

Figure 2: Seksyen in George Town. Source: GeoPortal, (2016) 
Penang Island has been divided into two districts which are northeast Penang Island and southwest Penang Island. Therefore, based on figure 1, George Town is one of the most populated among others region in the northeastern district with 198,298 (in '000) compared to another district. Thus, after identifying the most populated district, the site selection will be narrow down to more specific area based on the land use area for residential. According to Jabatan Perancangan Bandar dan Desa Pulau Pinang (2016), the overall total residential zone in George Town is $7,328,475 \mathrm{~m}^{2}$ with total 26 Seksyen (refer figure 2). Therefore, Seksyen 5 has been identifying as significant land use area for residential.

According to Mengual (2015), the selection of flat roof conditions was base on the criteria space, safety and accessibility. Furthermore the other criteria of selection of high rise building stated by Marion (2011) and Badami \& Ramankutty (2014), limited food access, low, medium income household, infrastructure surrounding, and also natural resources. Thus, the selection of sampling was done in two (2) numbers of potential high rise buildings from total eighteen (18) numbers. From the site survey that has been done, the potential of high rise building for urban farming is Krystal Height \& Greenlane Height Block $\mathrm{H}$ based on the criteria for selection of high rise building.

Based on figure 3 above, the total populations for this case study was overall total 963 units. According to Krojchie \& Morgan (1970), the sampling size for 950 populations needs 274 sampling. A survey conducted in Seksyen 5, George Town, Penang where 274 respondents were interviewed via structure questionnaire.

Table 1. List of condominium

\begin{tabular}{llll}
$\begin{array}{l}\text { Condominium } \\
\text { Name }\end{array}$ & $\begin{array}{l}\text { Total } \\
\text { Unit }\end{array}$ & $\begin{array}{l}\text { Percentage } \\
\text { Occupied }\end{array}$ & $\begin{array}{l}\text { Overall } \\
\text { Total }\end{array}$ \\
\cline { 1 - 2 } Kristal Height & 932 & $75 \%=699$ unit & 963 unit \\
\hline $\begin{array}{l}\text { Greenlane Height } \\
\text { Block H }\end{array}$ & 311 & $85 \%=264$ unit & \\
\hline
\end{tabular}

(Source:Author, 2018)

\subsection{Survey Design}

The process of research illustrates the data collection, analysis and the potential that for this study. This study conducted by using a questionnaire survey (Quantitative Methodology) to get a better understanding of the potential of rooftop urban farming. The target population for this research will be in the low-income urban areas. This is because the higher income groups in urban areas have, the higher capability to purchase foods, therefore less possible in food secures (Badami \& Ramankutty, 2014). The growth of urban poverty is growing as a result of the population and poverty has become urbanised. Thus, it affects the low, medium income household to be highly vulnerable to food insecurity due to the rising of food prices and falling wages and disposable household income. Therefore, the urban poor but not the poorest is potentially benefit from urban farming. Hence, the research is focused on urban poor because there form significant shares of urban populations in low-income countries.

The questionnaire was left close-ended questionnaire. The questionnaire consists of three sections. The first section requires the respondent to answer their demographic information. The second section is expressed to identify the knowledge about green rooftop. While for the third section is querying about their preference towards urban farming. In this section also include the knowledge of the respondent about the benefits of the urban farming towards environment, social and economy. The respondent will be asked to classify the background, knowledge, skill, challenges and the rooftop conditions. A distinction and result from the question which was deemed to be essential to identify how potential the urban farming in this urban area.

\subsection{Pilot Study}

This research evaluates the potential of high rise building residents toward rooftop urban farming. To accomplish the objective, the reliability test was used to test the reliability of the questionnaire. The reliability test used in this research will be Crobanch's alpha. In this research there is two stage of a pilot study which is:

\footnotetext{
$1^{\text {st }}$ Pilot Study

The first stage of pilot study contains ten sampling. The sampling is to test the validity of the questionnaire.

The Cronbach's alpha value for the first stage is 0.503 . From this result, it shows that the validity of this questionnaire contains inconsistency among the questionnaire's items and need revision.

\section{$2^{\text {nd }}$ Pilot Study}

The revised questionnaire for this second pilot study contains 30 sampling. For this time pilot study, the Cronbach's alpha was 0.901 . The revised questionnaire was omitting the open-ended question.
} 


\subsection{Result \& Discussion}

\section{Demographic Factors}

Table 2 shows that the respondent's distribution according to gender is almost equal. $51 \%$ respondent was male, and $49 \%$ were female. The race distribution indicated that the respondent was predominantly Chinese (52\%), followed by Malay (32\%), Indian (15\%) and others (2\%). Most of the respondent with monthly income range RM1001 - RM300 (56\%). While for the age of respondent, majority age 31-40 years old (44\%). An analysis of the education background showed that $39 \%$ are degree/master holder. While regarding occupation, $57 \%$ of the respondents work in private sectors followed by $24 \%$ in government sectors.

Table 2. Demographics

\begin{tabular}{llcc}
\hline Variable & Description & Frequency & Percentage \% \\
\hline Gender & Male & 139 & 51 \\
& Female & 135 & 49 \\
\hline Race & Malay & 87 & 32 \\
& Chinese & 141 & 52 \\
& Indian & 42 & 15 \\
& Others & 4 & 2 \\
\hline Monthly income & Below RM1000 & 34 & 12 \\
& RM1001-RM3001 & 153 & 56 \\
& RM3001 - RM4000 & 70 & 26 \\
& RM4001 - above & 17 & 6 \\
\hline Age & $15-20$ y & 16 & 6 \\
& $21-30$ y & 82 & 30 \\
& $31-40$ y & 121 & 44 \\
& $41 \&$ above y & 55 & 20 \\
\hline Occupation & Private & 8 & 3 \\
& Government & 74 & 27 \\
& Housewife & 84 & 30 \\
& Students & 108 & 40 \\
\hline Educational Background & Primary school & 8 & 3 \\
& Secondary school & 74 & 27 \\
& Certificate/diploma & 84 & 31 \\
& Degree/master/PhD & 108 & 39 \\
\hline
\end{tabular}

(Source:Author, 2018)

The availability of rooftop in case study area is suitable for the observation that has been done. Nevertheless, from the findings, indicates that $79 \%$ of the respondent has never visited the rooftop, but the respondent knows that there is a rooftop in this building with $85 \%$. This means that even though there is possible rooftop area for urban farming, yet still regarding the accessibility have not agreed to do urban farming.

\section{Skills \& knowledge}

Concerning the skills of the respondent, half of the respondents grow their foods at their house. This shows good atmosphere on creating urban farming on the rooftop. But only $55 \%$ of the respondents are not familiar with urban farming. The terms of urban farming as a lay man might confuse them as a lay man even though they are doing urban farming actually. An analysis of the knowledge or understanding towards the urban farming showed that $76 \%$ of the respondents do not know how to plant on the rooftop. $50 \%$ of the respondents agree that the implementation of urban farming should be on the rooftop. The remaining percentage is followed by balcony area (27\%), community gardens $(22 \%)$ and indoor (2\%). Most of the respondents get to know about urban farming from media electronics (48\%). That is means that the power of the internet nowadays is good in educating the people to start doing the urban farming in urban areas. Majority of the respondent has never been to any rooftop with farming. This showed that the urban farming is not well establish in Penang especially. In the respondent point of view, $43 \%$ said that the rooftop should be as a place for relaxation, followed by ambience or aesthetic (34\%), farming (12\%) and recreation (11\%).

\section{Economic, Social \& Environment Factors}

The factors that lead to the forming of urban farming on the rooftop are depending on the social factors, economic factors and also environment factors. Regarding the social factors, the willingness of the respondent to use rooftop as a place for farming is high with $69 \%$. Most of them are agreed that types of urban farming on the rooftop are suitable for soil production (53\%), hydroponics (20\%), soilless production (14\%) and aquaponics (12\%). Nevertheless, the existing rooftop needs to be upgraded regarding the security due to 
the majority respondents feel unsafe (82\%). When the respondents have been asked about the challenge in maintaining the garden, the majority answered that time is the most challenging factors.

This paper describes the result from the questionnaire survey of high rise residential building towards the potential in creating urban farming. The finding shows a significant conclusion which is high potential to implement urban farming on the residential rooftop. The implementation of urban farming depends on the space, skill \& knowledge, time and also budget.

\subsection{Conclusion}

This paper presents the findings from pilot study done in Seksyen 5, George Town. The finding shows that there is a potential in creating urban farming on rooftop. Although there are many constrain and limitation, but the benefit is tremendously more than providing food supply. Even though in Malaysia is still early stage of urban farming on rooftop, a strategic planning will help to boost the productivity. The support from various sectors will enhance in creating of urban faming on rooftop.

The finding from this study also shows that the implementation of urban farming on the rooftop is one of the solutions in creating the food resilient and sustainability. The local government can also play a role by inspiring the people to start growing their food at home. The local government also needs to feed the community with knowledge, equipment and the new technology of urban farming for those who would like to start growing their foods.

\section{Acknowledgement}

We would like to thank the reviewer for valuable comments, encouragement, and thoughtful ideas during the writing stage of this paper.

\section{References}

Asmat, I., Samad, M.H.A., Rahman, A.M.A., (2011). The Investigation Of Green Roof And White Roof Cooling Potential On Single Storey Residential Building In The Malaysian Climate.

Badami, M., \& Ramankuty, N., (2014). Urban Agriculture and Food Security: A Critique Based on an Asessment of Urban Land Constraints: Global Food Security., 4, 815 .

FAO,. (2007). Profitability and Sustainability of Urban and Peri-Urban Agriculture; Agricultural Management Marketing and Finance Occasional Paper, by Veenhuizen R.V., \& Danso, G., Rome.Italy

Geo Portal (2016). Unique Parcel Identifier (UPI). Retrieved May 7, 2016, from http://myliis3.mygeoportal.gov.my/upi/

Giraldo, D.P., (2008). Food security in development countries : a systematic perspectives. In International Conference of the System Dynamics Society.

Kortright, R. (2001). Evaluating the potential of green roof agriculture. Published by city farmer, Canada's office of urban agriculture. October. Urban agriculture notes. Retrieved Feb 17, 2016, from http://www.cityfarmer.org/greenpotential.html

Krojchie, R.V., \& Morgan, D.W. (1970). Determining Sample Size for Research Activities. Educational and Psychological Measurement, 30, 608.

Nur Hayati. H., Nur Huzeima, M.H., Asmat, I., (2016). Understanding The Concept Of Green Roof As Urban Farming: A Comparative Study. In International Conference on Sustainable Development and Livelihoods.

Rasmuna, M. M., \& Rashid, M. R. (2015). The Potential of Urban Farming Technology in Malaysia : Policy Intervention

RUAF. (2007). Profitability and Sustainability of Urban and Peri-Urban Agriculture; Agricultural Management Marketing and Finance Occasional Paper, by Veenhuizen, R.V., \& Danso, G., Rome.Italy.

Sanyé-Mengual, E. (2015). Sustainability assessment of urban rooftop farming using an interdisciplinary approach (Doctoral thesis), Universitat Autonoma de Barcelona, Brazil.

Tarmiji, M., Yaakob, U., Ayob, N. M., \& Mokhtar, A. S. (2012). Population and spatial distribution of urbanisation in Peninsular. Malaysia Journal of Society and Space, 2(2), 20-29. 